\title{
Yorùbá Movies and the Problem of Subtitling
}

\author{
Jacob Fádo $\square$ Rò $\square$ Olúdáre \\ Department Of Linguistics and African Languages, University Of Ibadan, Ibadan, Nigeria.
}

\begin{abstract}
Yorùbá movies producers seem to have devoted much attention to the visual qualityand the thematic thrust of their works to the detriment of some seemingly unimportant aspect of their products. One of these neglected or underestimated aspects is the issue of subtitles, the written translations of the dialogues in English Language. This paper selects seven Yorùbá movies for a detailed evaluation. Errors in concord, spelling, tense, aspect and wrong selection of words are very rampant in these movies such that one wonders why such neglect and carelessness should be allowed in such movies that are very rich in thematic thrusts and excellent in visual quality. These errors are not only highlighted, they are discussed, analysed and attempts have been made to propose what should have been the correct versions of the wrong translations that are pointed out. This paper throws a big challenge to films producers to pay attention to this important issue and allow specialists in different areas so that their products will not be lacking in quality.
\end{abstract}

\section{Introduction}

Subtitles are textual versions of the dialogues in films and television programmes, usually displayed at the bottom of the screen. They can take the form of written translation of a dialogue in a foreign language, or a written rendering of the dialogue in the same language, with or without added information to help viewers who are deaf or hard of hearing to follow the dialogue, or people who cannot understand the spoken dialogue or who have accent recognition problems. In the South-Western Zone of Nigeria, where Yorùbá is the predominant language, there is a need to do proper subtitling of movies produced, since these movies have audiences across and beyond the nation. This paper takes a look at some of these movies with the aim of identifying the errors committed in the process of subtitling them and proposing what ought to be the correct expressions. The paper also calls all stakeholders, especially, Yorùbá film producers, the Association of Nigerian Theatre Practitioners (ANTP) as well as the Nigerian Film and Video Censors Board to ensure quality production.

\section{Methodology}

Seven Yorùbá movies were selected for examination . These are: Bámitádé, Ayò $\square$, Kúléndé, İgbéraga, Àárín Ò $\square$ tá, Ògidì $\mathrm{O} \square \mathrm{mo} \square$ and Ilé $\mathrm{O} \square \mathrm{ko} \square$. These movies were carefully watchd in order to sort out the faulty subtitles. Having identified and analysed the errors that were contained in them, the researcher proposed what he thought should be the correct translations of the expression. Errors identified are concord, spelling, tense/aspect and wrong selection of words.

\section{Research Problem}

The Nigerian movie industry has come a long way in cinematographic transformation Okome, O. 1997; Olusola, S. 1981; Oyewo, G.B. 1998. It is without doubt occupying a centre stage as it has, over the years, taken different dimensions of showcasing what the industry knows how best to do. Ekwuazi, 1991; Ogunbiyi, Y. 1981; Dasylva, A.O. 2004. However, many of these movies are produced without any iota of professionalism in the business of the theatre. It is commonly observed that there is no clearly defined space for specialisation. An individual actor can be a producer, director and scriptwriter. This is done in order to reduce the unavoidable cost of production. The negative consequence of this is that Nigerian audience is fed with a body of junks. The most embarrassing aspect is the attempt made at subtitling these movies. These subtitles are marred with grammatical blunders that could be avoided if specialists in translation are allowed to handle the job Sunday, 2009.

\section{Data Presentation}

Table 1: Concord

\begin{tabular}{|l|l|l|l|l|l|}
\hline & Movie & Utterance & Subtitle & $\begin{array}{l}\text { Correct } \\
\text { Version }\end{array}$ & Error Analysis \\
\hline a. & $\begin{array}{l}\text { Áárín } \\
\text { Ò } \square \text { tá }\end{array}$ & $\begin{array}{l}\text { Ó ye } \square \text { kí a kúrò ní ibí } \\
\text { báyìi cos our lives is in } \\
\text { danger }\end{array}$ & $\begin{array}{l}\text { Our lives is in } \\
\text { gander }\end{array}$ & $\begin{array}{l}\text { Our lives are } \\
\text { in danger }\end{array}$ & $\begin{array}{l}\text { Lives is in plural so the } \\
\text { linking verb 'is' should be } \\
\text { 'are'. The word 'danger' is } \\
\text { wrongly spelt as gender. }\end{array}$ \\
\hline b. & Bamitálé $\square$ & İònú ò san gbèsè & Thinking & Thinking does & Thinking is singular, it \\
\hline
\end{tabular}




\begin{tabular}{|l|l|l|l|l|l|}
\hline & & & $\begin{array}{l}\text { don't pay } \\
\text { debts }\end{array}$ & not pay debts & $\begin{array}{l}\text { attracts singular 'do' verb, } \\
\text { which is 'does'. }\end{array}$ \\
\hline c. & Ayò $\square$ & Nǹkan ti ń bàjé $\square$ & $\begin{array}{l}\text { Things is } \\
\text { getting bad. }\end{array}$ & $\begin{array}{l}\text { Things are } \\
\text { getting bad }\end{array}$ & $\begin{array}{l}\text { The subject 'things' is } \\
\text { plural, it attracts a plural } \\
\text { verb 'are'. }\end{array}$ \\
\hline d. & $\begin{array}{l}\text { Ilé } \\
\text { O } \square \text { ko } \square\end{array}$ & $\begin{array}{l}\text { Bí ó s } \square \text { e máa ń s } \square \mathrm{e} \\
\text { nìye } \square \text { n. }\end{array}$ & $\begin{array}{l}\text { That is how } \\
\text { she behave. }\end{array}$ & $\begin{array}{l}\text { That is how } \\
\text { she behaves. }\end{array}$ & $\begin{array}{l}\text { She attracts a singular verb } \\
\text { 'behaves' and not 'behave'. }\end{array}$ \\
\hline e. & Ayò $\square$ & Ò $\square$ rò $\square$ ti bó $\square$ sórí. & $\begin{array}{l}\text { Things is } \\
\text { getting out of } \\
\text { hand. }\end{array}$ & $\begin{array}{l}\text { Things are } \\
\text { getting out of } \\
\text { hand. }\end{array}$ & $\begin{array}{l}\text { 'Things' is plural. It attracts } \\
\text { 'are' and not 'is'. }\end{array}$ \\
\hline f. & Kúléndé & $\begin{array}{l}\text { Ló } \square \text { wó } \square \text { ló } \square \text { wó } \square, \text { a ní } \\
\text { puló } \square \text { tì ilè } \square \text { méjì. }\end{array}$ & $\begin{array}{l}\text { Presently, we } \\
\text { has two plots } \\
\text { of land. }\end{array}$ & $\begin{array}{l}\text { At present, we } \\
\text { have two plots } \\
\text { of land. }\end{array}$ & $\begin{array}{l}\text { 'We' attracts 'have' and not } \\
\text { 'has'. Also, presently is } \\
\text { wrongly used. 'At present' } \\
\text { is better. }\end{array}$ \\
\hline
\end{tabular}

The word concord refers to 'agreement' between the different components (words) used in a piece of writing. Mainly, it refers to agreement between the parts of a sentence in forms of number and person to ensure accuracy or correctness. Basically, there are four dimensions:

(i) Subject-verb concord.

(ii) Time reference concord

(iii) Gender concord

(iv) Pronoun-antecedent concord

The concord problem highlighted in the data above has to do with the relationship between the subject and the verb. The rule of concord states that a singular subject must attract a singular verb, while a plural subject must attract a plural verb. Items a, c, e and f have plural subjects - lives, things, things and we respectively, thus they should attract the linking verbs are, are, are and have respectively. On the other hand and, items so and d thinking and she are singular, so they should attract the verb phrase of does not and the verb behaves respectively. So that we have (b) thinking does not pay debts. (d) that is how she behaves.

Table 2: Spelling

\begin{tabular}{|c|c|c|c|c|}
\hline Movie & Utterance & Subtitle & Correct Version & Error Analysis \\
\hline $\begin{array}{l}\text { Àárín } \\
\text { Ò } \square \text { tá }\end{array}$ & Inú ń run mí. & $\begin{array}{l}\text { I have stomarch } \\
\text { pain. }\end{array}$ & $\begin{array}{l}\text { I have stomach } \\
\text { pains. }\end{array}$ & $\begin{array}{l}\text { Stomach is wrongly spelt } \\
\text { as 'stomarch'. Also, pains } \\
\text { should also be used instead } \\
\text { of pain. }\end{array}$ \\
\hline Ayò $\square$ & Máà bìnúu & I'm soory. & I'm sorry. & $\begin{array}{l}\text { The word 'sorry' is } \\
\text { wrongly spelt as 'soory' }\end{array}$ \\
\hline Ayò $\square$ & $\begin{array}{l}\text { Tó o bá kúrò } \\
\text { lékòó, kò ye } \\
\text { kékòó kúrò lára } \\
\text { re } \square \text {. }\end{array}$ & $\begin{array}{l}\text { If Lagos } \frac{\text { deport }}{\text { should }} \\
\text { you, you } \\
\text { not deport Lagos. }\end{array}$ & $\begin{array}{lr}\text { If you depart } & \text { from } \\
\text { Lagos, } & \text { Lagos } \\
\text { should not } & \text { depart } \\
\text { from you. } & \\
\end{array}$ & $\begin{array}{l}\text { The verb 'depart' is } \\
\text { wrongly spelt as 'deport'. }\end{array}$ \\
\hline İgbéraga & Máà kúnlè $\square$ mó $\square$ & $\begin{array}{l}\text { Do not go on your } \\
\text { kneels. }\end{array}$ & $\begin{array}{l}\text { Do not go on your } \\
\text { knees. }\end{array}$ & $\begin{array}{l}\text { The word 'knees' was } \\
\text { wrongly spelt as 'kneels' }\end{array}$ \\
\hline Ayò $\square$ & $\begin{array}{l}\text { Ò bá ti so } \square \text { fún } \\
\text { dókítà ki ó ba } \\
\text { oyún náà jé } \square \text {. }\end{array}$ & $\begin{array}{l}\text { You should have } \\
\text { asked the doctor } \\
\text { to about it. }\end{array}$ & $\begin{array}{l}\text { You should have } \\
\text { told the doctor to } \\
\text { abort it. }\end{array}$ & $\begin{array}{l}\text { The word 'abort' was } \\
\text { wrongly spelt 'about'. }\end{array}$ \\
\hline Ayò $\square$ & $\begin{array}{l}\text { Mo ní láti bè } \square \text { ó } \square \\
\text { pé kí o má à dà mí } \\
\text { mó } \square \text {. }\end{array}$ & $\begin{array}{l}\text { I need to beg you } \\
\text { not to betroy me. }\end{array}$ & $\begin{array}{l}\text { I need to beg you } \\
\text { not to betray me. }\end{array}$ & $\begin{array}{l}\text { The word 'betray' was } \\
\text { wrongly spelt as 'betroy'. }\end{array}$ \\
\hline Kulende & $\begin{array}{l}\text { Nígbà tí ǹkan bá ń } \\
\text { dùn o ò ní kú. }\end{array}$ & $\begin{array}{l}\text { May you not die } \\
\text { when things are } \\
\text { rousy. }\end{array}$ & $\begin{array}{l}\text { May you not } \\
\text { when thie } \\
\text { rosy. }\end{array}$ & $\begin{array}{l}\text { The word 'rosy' was } \\
\text { wrongly spelt as 'rousy'. }\end{array}$ \\
\hline İgbéraga & $\mathrm{O}$ ti borí ìs $\square$ òro. & $\begin{array}{lr}\begin{array}{l}\text { You } \\
\text { overcome } \\
\text { obstance. }\end{array} & \begin{array}{r}\text { have } \\
\text { the }\end{array} \\
\end{array}$ & $\begin{array}{l}\text { You have overcome } \\
\text { the obstacle. }\end{array}$ & $\begin{array}{l}\text { The word 'obstacle' was } \\
\text { wrongly spelt as obstance'. }\end{array}$ \\
\hline $\begin{array}{l}\text { Arín } \\
\mathrm{O} \square \text { jà }\end{array}$ & $\begin{array}{l}\text { È } \square \text { yin gan an le } \square \\
\text { gò } \square \text { jù. }\end{array}$ & You are a big full & You are a big fool. & $\begin{array}{l}\text { The word 'fool' was } \\
\text { wrongly spelt as 'full'. }\end{array}$ \\
\hline
\end{tabular}

Table 2 above highlights nine spelling errors. The words stomach, sorry, depart, knees, abort, betray, rosy, obstacle and fool are misspelt as stomarch, soory, deport, kneels, about, betroy, rousy, obstance and full respectively. These errors could have been prevented if the translators had made use of a simple dictionary. Every dictionary shows the correct spelling of every word in the very first column. Translators should therefore make good use of dictionaries as a good guide in spelling. 
Table 3: Tense and Aspect

\begin{tabular}{|c|c|c|c|c|c|}
\hline a. & İgbéraga & $\begin{array}{l}\text { Èmi mo } \square \text { iyì re } \square \text {, } \\
\text { as } \square \text { o } \square \text { iyì e } \square \text { kò } \\
\text { dè } \square \text { ní ya mo } \square \\
\text { e } \square \text { lára. }\end{array}$ & $\begin{array}{l}\text { I value you. May } \\
\text { you not lost your } \\
\text { value. }\end{array}$ & $\begin{array}{l}\text { I appreciate you. } \\
\text { May you not lose } \\
\text { your value. }\end{array}$ & $\begin{array}{l}\text { The form 'lose' should } \\
\text { be used instead of lost. }\end{array}$ \\
\hline b. & İgbéraga & $\begin{array}{l}\mathrm{S} \square \text { èbí o so } \square \text { fún } \\
\text { mi pé ara re } \square \text { kò } \\
\text { yá ni? }\end{array}$ & $\begin{array}{l}\text { Didn't } \\
\text { pretended as if } \\
\text { you were sick? }\end{array}$ & $\begin{array}{l}\text { Didn't you pretend } \\
\text { that you were sick?/ } \\
\text { Didn't you tell me } \\
\text { that you were sick? }\end{array}$ & $\begin{array}{l}\text { The form 'pretend' } \\
\text { should be used since the } \\
\text { tense has been reflected } \\
\text { on the 'do' verb. The } \\
\text { phrase 'as if' is also } \\
\text { redundant. }\end{array}$ \\
\hline c. & İgbé & $\begin{array}{l}\text { Bí òdodo báyìi ní } \\
\text { e } \square \text { wà obìnrin tí ó } \\
\text { bá di àkókò kan , } \\
\text { òdodó ò } \square \text { hún á } \\
\text { wá di ohun tí a ń } \\
\text { fi e } \square \text { sè } \square \text { tè } \square\end{array}$ & $\begin{array}{l}\text { Beauty is like the } \\
\text { flower in full } \\
\text { bloom at a certain } \\
\text { time, it will } \\
\text { withered and } \\
\text { become letters. }\end{array}$ & $\begin{array}{l}\text { Beauty is like the } \\
\text { flower in full } \\
\text { bloom, at a certain } \\
\text { time, it will wither } \\
\text { and } \\
\text { useless. }\end{array}$ & $\begin{array}{l}\text { Wrong use of tense } \\
\text { 'withered' instead of } \\
\text { wither. The modal } \\
\text { auxillary } \\
\text { presupposes 'future.' }\end{array}$ \\
\hline d. & İgbéraga & $\begin{array}{l}\text { İànló } \square \text { wó } \square \text { re } \square \\
\text { tí mo fé } \square \text { ni kí n } \\
\text { sá kàn manage } \\
\text { níbí. }\end{array}$ & $\begin{array}{l}\text { The only help I } \\
\text { want from you is } \\
\text { to } \underline{\text { be }} \\
\text { accommodate for } \\
\text { a short while here. }\end{array}$ & $\begin{array}{l}\text { The only favour I } \\
\text { need from you is to } \\
\text { be accommodated } \\
\text { for a while here. }\end{array}$ & $\begin{array}{l}\text { 'Accommodated' } \\
\text { should be use instead of } \\
\text { 'accommodate'. }\end{array}$ \\
\hline e. & İgb & $\begin{array}{l}\text { To rí è } \square \text { náà la } \\
\text { s } \square \text { e wá láti wá } \\
\text { bè } \square \text { yín. }\end{array}$ & $\begin{array}{l}\text { That's why } \underline{\text { we }} \\
\underline{\text { decides to come }} \\
\text { and apologise. }\end{array}$ & $\begin{array}{l}\text { That's why } \underline{\text { we }} \\
\underline{\text { decided to come }} \\
\text { and apologise. }\end{array}$ & $\begin{array}{l}\text { Wrong tense 'decides' } \\
\text { instead of 'decided'. }\end{array}$ \\
\hline f. & Ayò $\square$ & $\begin{array}{l}\mathrm{S} \square \text { é o so } \square \text { fún } \\
\text { me pé o fé } \\
\text { ré } \square \text { ńtì ilé? }\end{array}$ & $\begin{array}{l}\frac{\text { Did }}{\text { you }} \underline{\text { will }} \text { rent a } \\
\text { house? }\end{array}$ & $\begin{array}{l}\text { Did you tell me you } \\
\text { would rent a house? }\end{array}$ & $\begin{array}{l}\text { 'Tell' should replace } \\
\text { 'told' since the 'do' } \\
\text { verb takes the past } \\
\text { form. Also 'would' } \\
\text { should replace 'will'. }\end{array}$ \\
\hline g. & Ayò $\square$ & Kíni o so $\square$ ye $\square$ n? & $\begin{array}{l}\text { What did you just } \\
\text { said? }\end{array}$ & $\begin{array}{l}\text { What did you just } \\
\text { say? }\end{array}$ & $\begin{array}{l}\text { 'Say' should replace } \\
\text { 'said'. }\end{array}$ \\
\hline h. & Ayò $\square$ & $\begin{array}{l}\text { Mo ti s } \square \text { àlàyé fún } \\
\text { un. }\end{array}$ & $\begin{array}{l}\text { I've explain to } \\
\text { her. }\end{array}$ & $\begin{array}{l}\text { I've explained to } \\
\text { her. }\end{array}$ & $\begin{array}{l}\text { 'Explained' should } \\
\text { replace 'explain'. }\end{array}$ \\
\hline i. & Ayò $\square$ & $\begin{array}{l}\text { Kí ló dé tí gbogbo } \\
\text { eléyií fí s } \square \mathrm{e} \square \text { lè } \square \\
\text { láàárín wa? }\end{array}$ & $\begin{array}{l}\text { Why did all these } \\
\text { happened between } \\
\text { us? }\end{array}$ & $\begin{array}{l}\text { Why did all these } \\
\text { happen } \\
\text { us? }\end{array}$ & $\begin{array}{l}\text { The form 'happen' } \\
\text { should } \\
\text { 'happened'. }\end{array}$ \\
\hline $\mathrm{j}$. & Ayò $\square$ & $\begin{array}{l}\text { Ò bá mó } \square \text { ti sá } \\
\text { jáde. }\end{array}$ & $\begin{array}{l}\text { You ought not to } \\
\text { have ran outside. }\end{array}$ & $\begin{array}{l}\text { You ought not to } \\
\text { have run awayl } \\
\text { You should not } \\
\text { have run away. }\end{array}$ & $\begin{array}{l}\text { The form 'run' should } \\
\text { replace 'ran' since it is } \\
\text { preceeded by 'have'. }\end{array}$ \\
\hline
\end{tabular}

Table 3 highlights ten errors connected with tense and aspect. Tense and aspect are very important to correct expressions in English language. In item 'a' lost which is the past tense of lose is selected instead of lose. The whole expression is a wish or prayer - "May you not lose your value. So the selection of lost is wrong, in the context. In item b, the verb 'pretended' is selected instead of 'pretend'. Already tense has been reflected on the auxiliary verb 'did'. Once the auxiliary verb has been inflected for past, the main verb should be left in the present form, so we should have "didn't you pretend" instead of "didn't you pretended." Apart from that, the expression, 'as if' is already incorporated in the word 'pretend', so the use of 'pretended as if sounds tautologeous. It should be 'pretend' alone. In item 'c' the modal auxiliary 'will' is in the future tense, so joining a verb in the past tense 'withered' makes the expression wrong, so we should have 'will wither' and not 'will withered'.

In item ' $\mathrm{d}$ ', the word 'accommodate' is wrong because it is preceded by the verb 'be'. Once a verb is preceded by 'be' it must attract the past rticiple and not the simple present again. Therefore it should be rendered as 'be accommodate' ' $d$ ' and not 'be accommodate' as we have it. Item 'e' talks about an action which took place in the past so it should be in the past tense "we decided", and not "we decides." Item ' $\mathrm{f}$ ', involves the problem of marking tense twice that is on the auxiliary verbs and the main verb. We have discussed this in item be above. The expressions should read as follows:

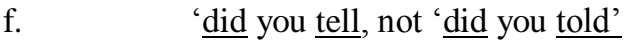

g. ' did' you just say', not '

h. $\quad$ 'why did these happen., not 'why did these happened. Item ' $h$ ' is a problem of aspect. The expression should be rendered. I've explained' and not 'I've explain'. Item ' $\mathrm{j}$ ' is also connected with aspect. The expression should be rendered 'have run' and not 'have ran'. 
Table 4: Wrong Selection of Words

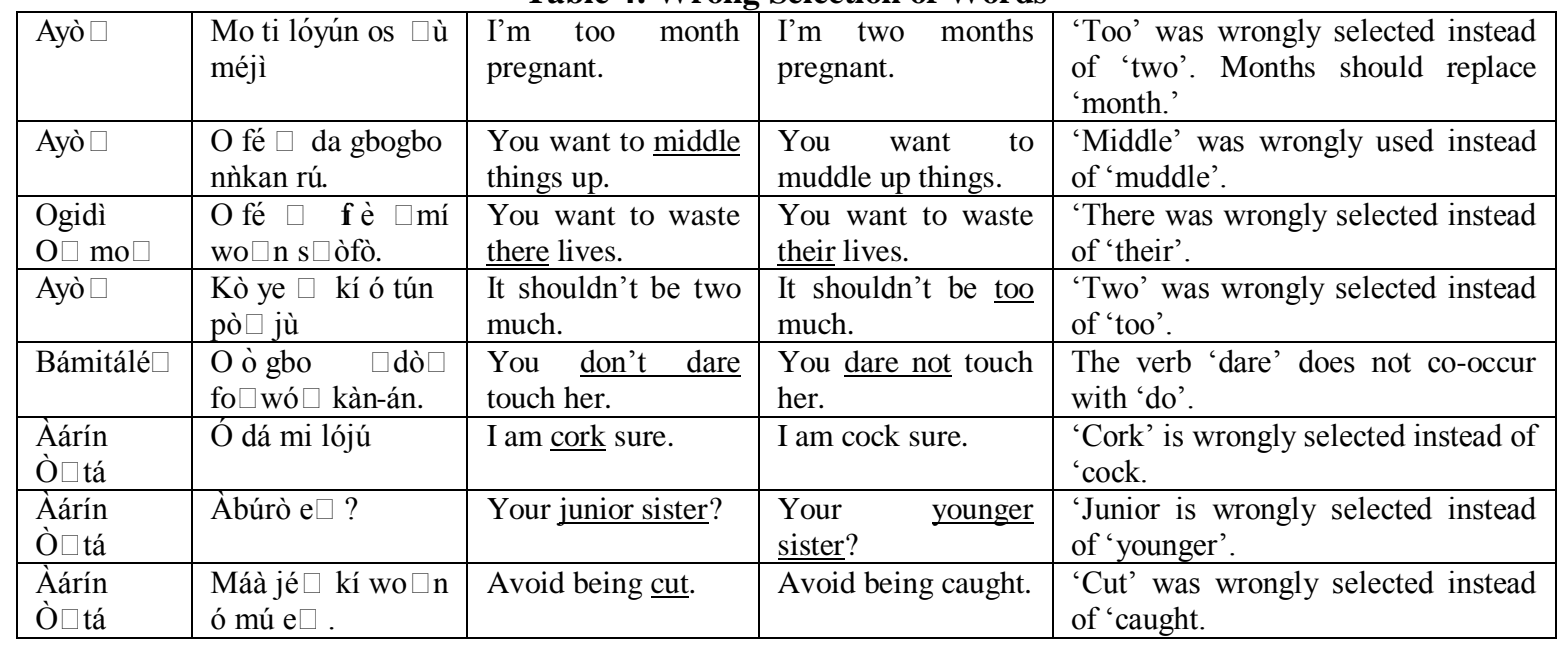

Table 4 highlights eight cases of wrong selection of words. The expressions month, middle there, two, don't dare, cork sure, junior sister and cut are wrongly selected instead of months, muddle, their, too, dare not, cock sure, younger sister and caught.

\section{The Implication of the Findings}

The implication of the above findings is that Yorùbá films makers are contributing negatively to lowering the standard of English language in Nigeria. Their products are watched daily by children, young adults, adults, and males and females throughout the South Western Zone of Nigeria and across the nation. Instead of contributing their quota towards uplifting the standard of the English language in the country, they are doing otherwise. In so doing, they are misleading millions of people who daily watch their products many of whom have mistaken them for models. To reverse this trend, movies producers should henceforth ensure that specialists are involved in subtitling their words. They should go an extra mile by allowing linguists to do proper editing of such subtitles, even though, this may involve more costs, "the end will justify the means" as the economists would say. Many of their fans would not mind spending more to purchase their products once they are sure that they are rich in quality in terms of visual output, thematic thrust, language and standard translations.

\section{Conclusion}

A very careful look at the errors identified in these subtitles suggests that Yorùbá film producers only pay attention to the visual quality and the thematic thrust of the movies. It is not enough for the industry to be concerned only with the visual quality and the thematic thrust, attention should equally be given to the grammaticality and accuracy of the subtitles for the benefit of audience who do not speak Yorùbá Wilmeth, 2006. This poses a challenge to the Association of Nigerian Theater Art Practitioners (ANTP) to wake up to its responsibilities. The Nigerian Film and Video Censors Board usually have a role to play in ensuring that these film producers improve the quality of the work in all ramifications. Film producers also should allow professionalism and specialisation of processes. Specialists in different aspects of the profession should be employed to handle the different areas of the work, not minding the cost. The end would no doubt justify the means if quality is improved.

\section{REFERENCES}

[1]. Dasylva, A.O. 2004. Studies in Drama. Ibadan: Stirling-Horden Publishers (Nig.) Ltd.

[2]. Ekwuazi, H. 1991. Film in Nigeria. Jos: Nigerian Film Corporation.

[3]. Ogunbiyi, Y. 1981. Nigerian Theatre and Drama: A Critical Profile. Nigerian Theatre and Drama: A critical course book. Ed. Y. Ogunbiyi. Lagos: Nigeria Magazine. 3-53.

[4]. Okome, O. 1997. The Context of Film Production in Nigeria: The Colonial Heritage. Cinema and Social Change in West Africa. Eds. O Okome and J. Hagnes. Jos: Nigerian Film Corporation. 26-40.

[5]. Olusola, S. 1981. The Advent of Television Drama in Nigeria. Nigerian Theatre and Drama: A critical course book. Ed. Y. Ogunbiyi. Lagos: Nigerian Magazine. 357-369.

[6]. Oyeleye, L Ed. Use of English: Tertiary Course Book: Ibadan: Agbo aasREO Publishers P. 58-81.

[7]. Oyewo, G.B. 1998. Professional Theatres in Nigeria: A Personal Memoir. Unpublished M.A. Dissertation, University of Ibadan, Ibadan.

[8]. Soyinka, W. 2000. Theatre in African Traditional Cultures: Survival Pattern. Modern African Drama. Ed. Biodun Jeyifo. New York. W.W. Norton. 
[9]. Sunday, A.B. 2009. 'Concord and Agreement,' Oyeleye, L. Ed. Use of English: A tertiary course book: Ibadan: Agbo Areo Publishers. Pp. 58-81.

[10]. Sunday, A.B. 2009. 'Concord and Agreement.'

[11]. Vivian, A. 2010. The translation of Yorùbá proverbs in Wole Soyinka's "The forest of a thousand demons . A seminar paper presented at the Department of English, University of Ibadan.

[12]. Wilmeth, D.B. 2006. Theatre. The world book encyclopedia. Chicago: World Book, Inc. 232-233. 